\title{
The Influence of the Socio-cultural Environmental Factors on the Marketing of Cultural Institutions of Latvia
}

\author{
Tatjana Golubkova*, Alla Iljina, Mg.oec \\ Department of Regional Economics and Economic Policy, Baltic International Academy, Latvia
}

Copyright $\mathrm{C} 2018$ by authors, all rights reserved. Authors agree that this article remains permanently open access under the terms of the Creative Commons Attribution License 4.0 International License

\begin{abstract}
The article deals with the socio-cultural factors of the macro-environment which can influence on the production and distribution of cultural products in Latvia. Among the main factors the level of education, social stratification, attitude in the society towards charity and culture as a whole are emphasized. Using the materials of the European studies and the results of the carried out survey of visitors of the state institutions of culture of Latvia, the authors carry out a comparative analysis of the influence of social and cultural factors on the European and Latvian market of the cultural products.
\end{abstract}

Keywords Socio-cultural Factors, Cultural Product, Marketing of Cultural Institutions

\section{Introduction}

In the system of marketing of cultural institutions, the study of the socio-cultural factors of the macro-environment plays a special role because the production and consumption of cultural products are closely related to those traditions, attitudes, life values and stereotypes of behaviour which are fixed in the society. Such elements of culture as value, traditions, education, social norms have a significant impact on the lifestyle of people [1]. These factors influence on the nature of the products produced, method of production, labour conditions, demand for goods and services and much more. Describing the external socio-cultural environment of cultural institutions, F. Colbert writes that social values play a leading role in the marketing of a product of culture with the change of these values the habits of the consumer are changed [2]. Taking into the consideration that cultural preferences are passed on from generation to generation an important role plays the family, the attitude towards the upbringing of children, their involvement in certain kinds of leisure activities [3].

Moreover, along with the influence that social and cultural factors have on the cultural product, it can be said that the product itself to a great extent forms this environment. Culture and art contribute to the solution of many problems in society, in particular, increase social capital [4], improve the psychological and physical well being of people [5], improve academic performance of students [6], are the catalyst of improvement of cities [7], contribute to the identification of a person with a certain group [8]. Of particular importance is the interinfluence in the light of the preservation of traditional European cultural values. As the President of the European Commission José Manuel Barroso noted, "Culture and creativity are important driving forces for personal development, social cohesion and economic growth. Today's strategy, which contributes to the inter-cultural understanding, confirms the place of culture at the heart of our policy". [9]

\section{The Methods of the Research}

The survey method was chosen as the main quantitative method, the goal of which was to compare the activity of visiting of cultural institutions of Latvia with the socio demographic and economic characteristics of the respondents. A questionnaire was developed, including 12 questions. The questions were closed-ended since this type of question is easier for respondents to process and more convenient for the researcher to code and analyse. [10] [11] To ensure the representativeness of the research, the questionnaire was conducted both by personal attendance, in the presence of the researcher - surveyor (104 questionnaires), and by sending questionnaires by e-mail (113 questionnaires) and through social networks (183 questionnaires). The time of conducting a survey: October - November 2017. A total of 400 respondents took part in the survey - residents of Latvia over the age of 18 . The 
statistical processing of data, obtained during the survey was carried out, using grouping, comparison and cross tabulation. The calculations were performed, using computer programs Excel and SPSS. The method of cross tabulation, using the SPSS programs helps to identify the connections between different variables [12] and its application allowed identifying certain patterns in the consumption of the cultural product of the state institutions of Latvia among various social and economic groups. The method of comparative analysis was also used with the help of which was compared the data obtained during the survey conducted by the authors with the results of studies carried out by European institutions, in particular, the research "European Cultural Values"[13], conducted on the request of the European Commission. The method of analysis of the secondary information: the statistical data, provided by the Ministry of Culture of Latvia and foreign cultural institutions helped to obtain additional information on analysed topic. During the preparation for conducting research, theoretical sources were studied. For today the topic of the influence of sociocultural factors directly on consumption of cultural products in Latvia was not considered. However, it can be noted that many foreign researchers pay great attention to this topic, as a rule, scientific publications are devoted to certain directions of art and entertainment. Thus, it is possible to emphasize works in which the influence of sociocultural factors on the attendance of theatres (Ateca-Amestoy V. [14], Bernstein J. S. [15]), museums (Pop E.L. \& Borza A. [16]; Brida J. G., Meleddu M. \& Pulina M. [17]), demand in the entertainment industry (Bizzozero P., Flepp R. \& Franck E. [18]; Dessy O. \& Gambaro M. [19]), visiting cinemas (Macmillan P. \& Smith I. [20]; Sisto A. \& Zanola R. [21] is examined.

\section{Results and Findings}

Most of Latvian studies, devoted to the influence of sociocultural environment on the consumption of cultural product are conducted among visitors of specific cultural institutions. Thus, the marketing services of theatres, museums and other cultural institutions have a sufficient amount of information about their audience, but they don't get the opportunity to collect information, contributing to its expansion.

In order to identify the most significant opportunities and threats on the part of socio -cultural factors, the cultural organizations must take into the consideration such trends as changes in the level of education of consumers, traditions of leisure activities, attitude towards the participation in charity, etc.

During the research conducted by the authors was compared the activity of visiting to such state cultural organizations as theatres, concerts, exhibitions halls and museums with the following characteristics: age, gender, social status, the level of education, economic status, place of residence and nationality.

According to the results of cross - tabulation, it was concluded that the most marked impact on the frequency of visits have such characteristics as:

1) level of education -among people with secondary education more than once a month cultural events attend $5.9 \%$ of people, $18,1 \%$ with the bachelor degree, and $27 \%$ with the master degree, while once a year and less often the opposite statistics is observed: $55.6 \%, 36.6 \%$ and $17.6 \%$ respectively.

Taking into the consideration that the level of education in Latvia has grown significantly in recent years (thus, in the period from 2000 to 2011 the number of people with higher education increased by almost $10 \%$ (from $13.9 \%$ to $23 \%$ ) [22] and this growth trend continues to exist, it can be concluded that the need for obtaining cultural product will be steadily increasing.

2) occupation -among such groups as pensioners, students and house person, the indicators of the frequency of visits more than 1 every six months is significantly higher than among active workers $61.9 \%, 78.4 \%$ and $90 \%$, respectively, while for the category of businessmen, managers and employed people they make up $37 \%, 25 \%$ and $51,3 \%$;

3) the place of residence -the activity of attendance essentially depends on the place of residence of respondents, do, for example, the residence of the capital of Latvia of Riga city showed the greatest activity: $37.6 \%$ visit once a month and more often, residents of other major cities of Latvia $-23.2 \%$, but those, who live in rural areas only $2.7 \%$.

4) it was also revealed that the majority of respondents prefer joint visits of cultural events only $13.3 \%$ answered that they come to cultural institutions alone, most often this is a visit with a partner $-30.8 \%$, with friends -22.5 , with children $16 \%$.

However, significant differences in such characteristics as age and gender were not revealed. A certain pattern also can be observed between the economic situation and frequency of visit; the respondents with higher incomes more often, visit cultural institutions, but these differences are not so significant. More noticeable differences among groups with different situation were revealed in the consumption of additional products and services during the placement of cultural events: only $2.2 \%$ among people with low incomes (less than 300 Euro per month) responded that they always use additional services, while among people with the highest incomes (more than 1000 Euro) this indicator makes up $70.8 \%$.

The obtained data were compared with the results of similar studies which were conducted in foreign countries.

Thus, according to the statistical survey, conducted in 
2017 in Great Britain at least once a month museums and concerts, visit $24 \%$ of respondents with higher education, $18 \%$ with the secondary education and $6 \%$ with the education lower than secondary education, while for those, who never visit these figures make up $4 \%, 4 \%$ and $11 \%$ respectively [23]. The study, conducted by Martin Falk and Tally Katz-Gerr in 24 countries of the European Union has shown that among individuals with higher education the number of visitors of museums, art galleries and historical monuments make up $70 \%$, with the secondary education - $46 \%$ and with the basic education only $26 \%$ [24]. The study also found that the level of education is the most important characteristic which determines the probability and number of visits of cultural institutions, outstripping in the order of importance the economic factors.

The fact that the education becomes more important than the income of households in increasing the probability and number of visits means that the human capital is more than economic capital as a factor of cultural inequality.

An important sociocultural factor which has a significant impact on the consumption of products, including the products of culture [25] is the social stratification of society and identification of people from the point of view of belonging to a particular socio-cultural group. According to M. Weber [26] self- identification with one or another social group identifies the lifestyle as a kind of self-expression of individuals. To distinctive features of belonging to a particular class usually refer the availability of a certain social status, education, occupation, the level of incomes and values. In the process of selecting different goods and brands the representatives of the social classes have certain common preferences. In the developed Western countries, where is formed a fairly stable division of society into 6 main classes: upper-upper, lower-upper, upper-middle, lower-middle, upper-lower, and lower-lower, the corresponding structure of consumption is formed, including in the field of culture, as the representatives of the first three social classes are more inclined to attend art auctions and galleries, dancing performances, operas, theatres, museums, concerts and other original cultural events, while individuals, who has lower social status prefer to visit cinemas, shows, entertainment shows [27].

Social stratification in the post-Soviet space is still not clearly defined because often such criteria as education, cultural preferences, and profession don't correspond to the level of income that can significantly complicate the activity of marketing specialists in the field of culture. Latvian researchers in the early 1990s identified three main classes: rich (3\%), middle class (12-13\%) and the poor (the rest of the population) [28]. By the end of 1990- $s$ the data of the studies were more optimistic, the middle class in 1999 already made up 30-35\% of the inhabitants of Latvia [29]. In 2009 the self-identification with the middle class in Latvia was already $62.8 \%$ [30] and as the main criteria of belonging act economic status, profession and education.

At the same time, as the results of our research showed in Latvia today the approach based on the offer of the cultural product, depending on the belonging of potential consumers to a certain class will be effective: from the mentioned criteria only the level of education has a significant influence on visiting cultural institutions, provision of additional services, organization of events on promotion of the product and etc.

Another important socio-cultural aspect that influences on the marketing activity in the field of culture can name the attitude in the society towards the charity. Made annually since 2010 Charities Aid Foundation Worldwide Index in 153 countries shows that at the heart of the propensity of the population of one or another country to provide assistance not only lies on precisely traditions, but not economic factors. Thus, in 2015, the top ten leaders in the field of charity along with the USA, Canada, New Zealand and Britain include Myanmar and Sri Lanka, while, for example, France France is on the 74th, Russia is on the 129th place. Latvia is in the rating of CAF in 2015 was only on the 110th place, along with this in comparison with 2014 it dropped to 21st position [31].

The field of culture traditionally needs the external sources of financing, including the support of patrons of the arts and philanthropists and existing traditions and trends have a significant influence on the development of this direction. In countries, where such a tradition is fixed, for example, in the USA and Great Britain a significant share of the budget of cultural organizations makes up, namely donations of visitors, who leave, when buying tickets or when they visit theatres, museums, concert halls.

The results of the survey, conducted by the authors show that a certain part of consumers of the cultural product $(7.3 \%)$ considers the prices for it in the state institutions of Latvia is understated and is ready to make additional donations. However, despite that fact that in recent years a fairly successful experience of cooperation of cultural organizations with major patrons and sponsors has emerged in Latvia, practically none of them provides opportunities for small mass donations. At the same time, the experience of the largest charity fund Ziedot.lv [32] in Latvia shows that a convenient, simplified scheme of donations (bank transfer from the website of the organization, call to a charity phone number, registration of regular payments) allows collecting substantial funds due to the donations and this experience can be used by cultural organizations.

One of the most important factors, influencing on the consumption of the cultural product is the attitude towards culture in the society as a whole. In 2007 on the initiative of the European Commission a large- scale research was conducted, among the main goals of which was to find out the significance of culture for the citizens of the European Union [13]. The results of the research allow comparing the data, obtained during the survey of residents of Latvia with 
the average European indicators. This survey showed that the importance of culture for Latvians is just as important as for Europeans in general: $77 \%$ of respondents consider that culture is important; one can observe a slight decrease among the indicator "very important" by $6 \%$, while the share of responded "fairly important" by $6 \%$ higher. (See Figure 1). This factor can be assessed as reflecting a positive interest to cultural products that indicates to a fairly large market of its potential consumers.

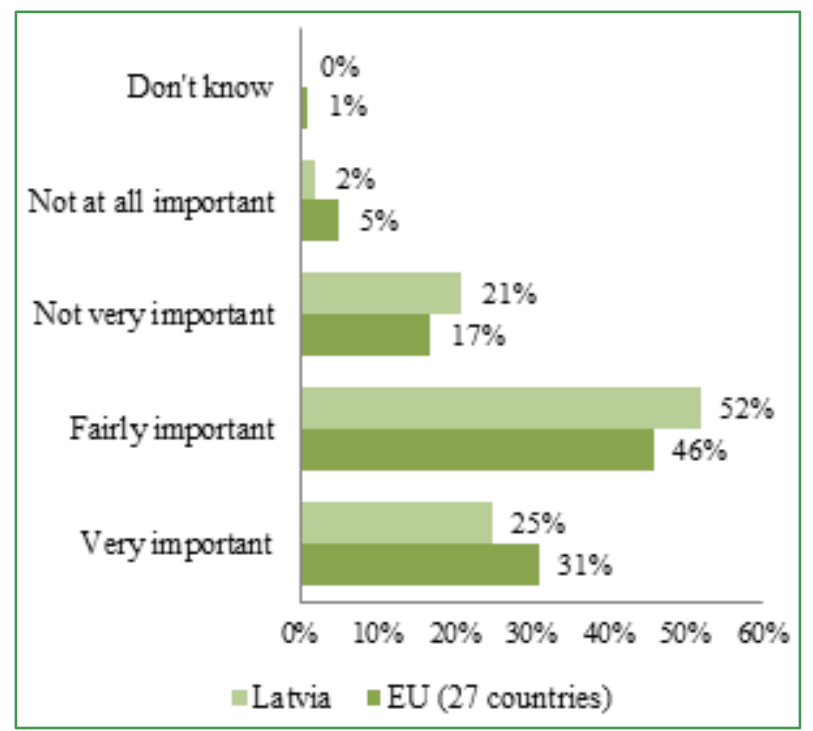

Figure 1. Distribution of responses of respondents to the question "How important is culture to you personally?" (Developed by the authors)

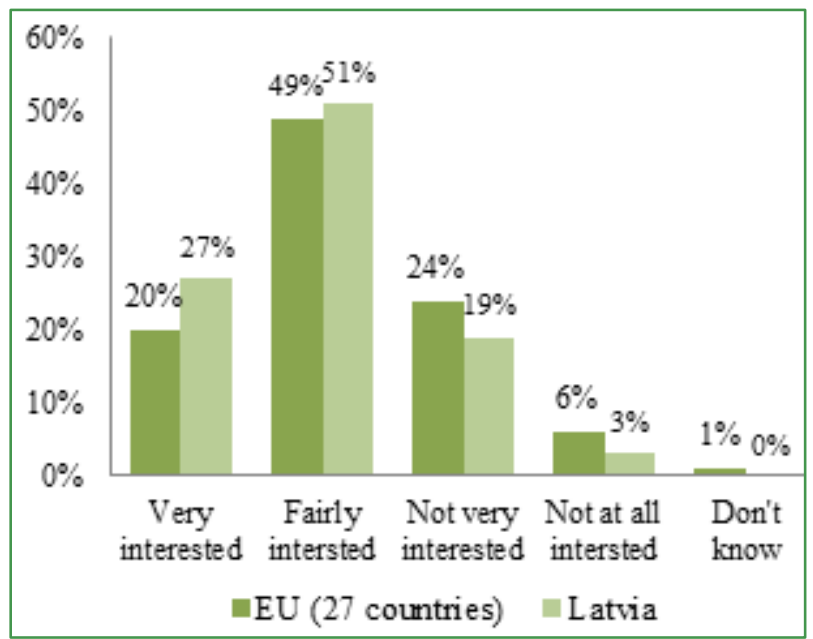

Figure 2. "Distribution of responses to the question „To what extent are you interested in the arts and culture in your own country?" (Developed by the authors).

Particularly important for the inhabitants of Latvia was the attitude towards the national culture and art of their country. In figure 2 the distribution of responses is shown, from which it can be concluded that for $78 \%$ of respondents the national culture of Latvia presents the substantial interest that is in 9\% higher than the European indicators. Such significant high indicators are the guarantee that the support of the Latvian culture on the part of the state authorities and commercial structures (in the form of sponsor and charitable assistance) will be positively evaluated by the audience.

The responses also were indicative, characterizing the attitude towards the cultures of the other European countries (See Figure 3).

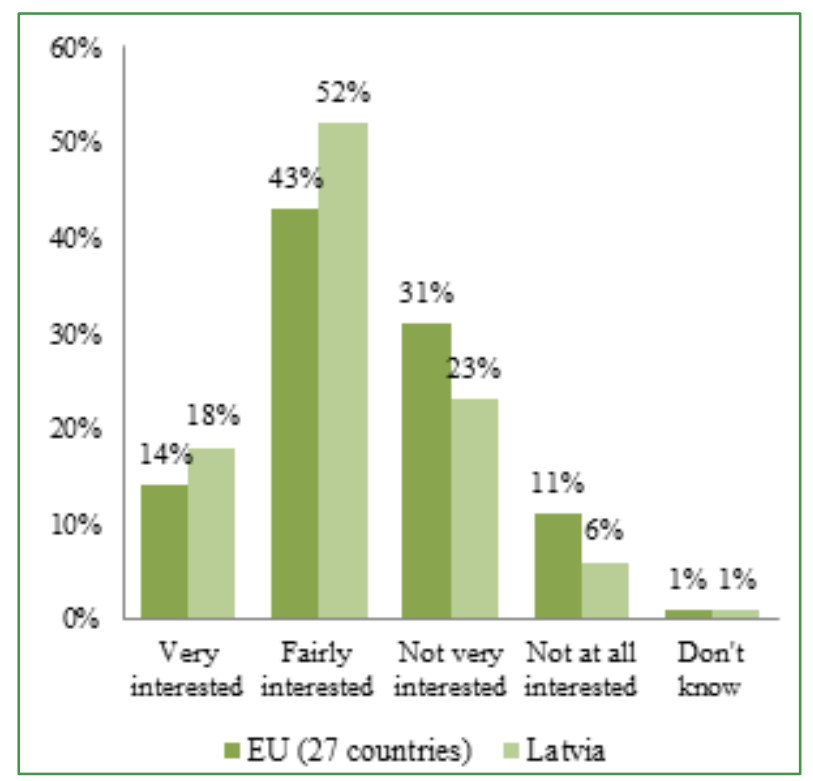

Figure 3. "Distribution of responses to the question, To what extent are you interested in the arts and culture of the other European countries?" (Developed by the authors)

As can be seen from figure 3, here the gap between the Latvian and Central European indicators is even more significant: a share of Latvians, showing interest to other national cultures made up $70 \%$, while for Europeans this indicator equals to $57 \%$. These results can indicate to a significant interest in the consumption of imported cultural product (tours of foreign performers, exchange of museum exhibits, etc.).

It should be noted that for cultural institutions of Latvia is typical a sufficiently high level of offer of new product. Thus, the results of the research, conducted by the Baltic Institute of Social Sciences showed that Latvian theatres produced 11 premiers on an average per year, while for theaters of three European countries, in which spectators are more active in visiting-Finland, Estonia and the Netherlands - these figures made up 10, 9 and 2 premiers, respectively. [33]

The interest of Latvians to the culture also was confirmed during the research of the authors: of those respondents, who visit cultural institutions, $53.8 \%$ did it more often than once a year (See Figure 4).

As can be seen from the figure 4 , the largest number of respondents -28.5 percent visit the cultural institutions 1- 2 times per half a year, while it is possible to note a sufficiently large proportion of the more frequent visit, making totally $25.3 \%$. 


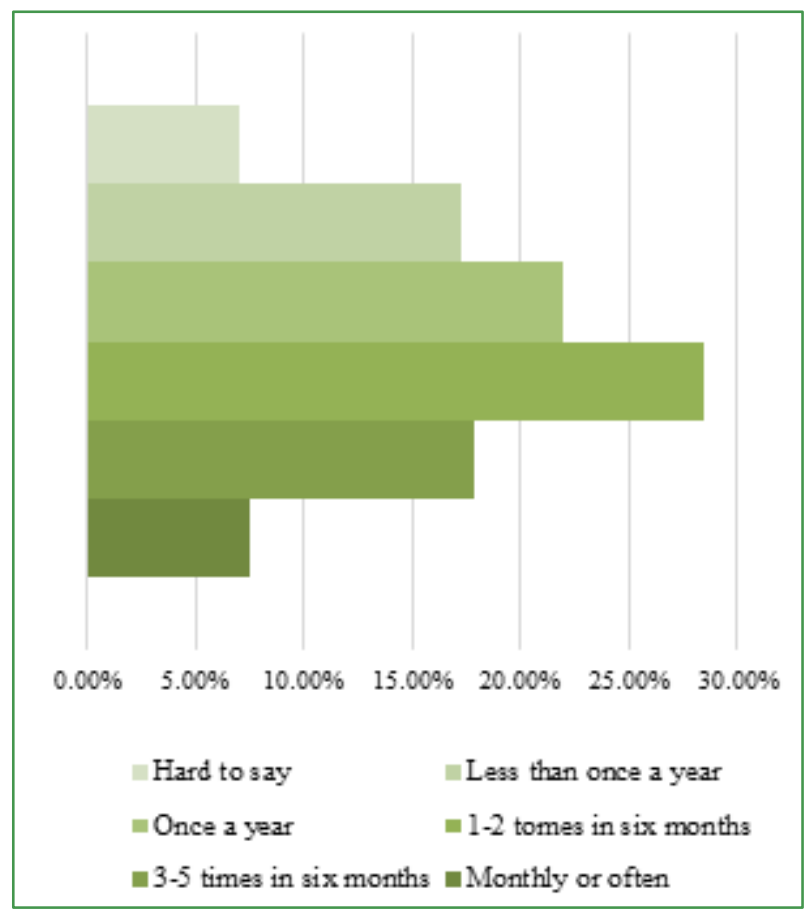

Figure 4. Frequency of visits of cultural events, organized by the state institutions of culture

The mentioned data show the inhabitants of Latvia are inclined to active consumption of products of the cultural institutions that is an important socio-cultural factor, which has a positive influence on the production and distribution of cultural products.

\section{Conclusions}

Thus, it can be concluded that the socio-cultural factors play an important role in the consumption of a cultural product. Such factors as the level of education, place of residence, occupation influence on the frequency of visiting cultural events. The data obtained during the survey conducted by the European researchers. At the same time, some differences in the assessment of social stratification on the consumption of cultural products, which in Latvia is less dependent on belonging to a particular social group than in developed Western countries. During the survey, a segment of consumers ready to make donations to cultural institutions and this direction of marketing activities, which is not yet represented in cultural institutions of Latvia can contribute to their financial situation. The activity which residents of Latvia show in visiting cultural events and interest in both local and foreign culture speaks of the high potential of this field. Thus, before the marketing services of state cultural institutions set important tasks to meet the cultural needs of residents and consideration of socio-cultural factors in the process of segmentation of consumers, the development of cultural product, its promotion, the formation of prices, attraction of additional funds can have a positive effect on the effectiveness of this activity.

\section{REFERENCES}

[1] Adeleke, A., Oyenuga, O.O. \& Ogundele, O.J.K. Business Policy and Strategy. Mushin, Lagos: Concept Publications Limited. (2003)

[2] Colbert, F., Nantel, J., Bilodeau, S. \& Rich J. Marketing kultury i iskusstva. Izdatel stvo: Vasin A.I. (2004). (In Russian)

[3] Barni, D., Ranieri, S., Scabini, E. \& Rosnati, R. Value transmission in the family: Do adolescents accept the values their parents want to transmit? Journal of Moral Education, 40(1), pp. 105-121. (2011)

[4] Williams, D. Creating social capital: a study of the long-term benefits from community based arts funding. Adelaide, S. Aust.: Community Arts Network of South Australia. (1995)

[5] Baklien, B. Culture is Healthy. International Journal of Cultural Policy 7. pp. 235-257. (2000)

[6] Fiske, E. B. Champions of change: the impact of the arts on learning. Washington, DC: Arts Education Partnership President's Committee on the Arts and the Humanities. (1999)

[7] Costello, D.J. The Economic and Social Impact of the Arts on Urban and Community Development. Humanities and Social Sciences. Pittsburgh: University of Pittsburgh. pp. 1333-A. (1998)

[8] Guetzkow, J. How the Arts Impact Communities: An introduction to the literature on arts impact studies. Princeton University. (2002)

[9] First-Ever European Strategy for Culture: Contributing to Economic Growth and Intercultural understanding/ European Commission. Available at http://europa.eu/rapid/press-release_IP-07-646_en.ht $\mathrm{m}$

[10] Wilson, C. Credible Checklists and Quality Questionnaires: A User-Centered Design Method. Waltham: Morgan Kaufmann. (2013)

[11] Bailey, K. D. Methods of Social Research, 4th ed. New York: The Free Press. (2008)

[12] Paura, L., Arhipova I. Advantages and Disadvantages of Professional and Free Software for Teaching Statistics. Information Technology and Management Science. Vol. 15, pp. 9-14. (2012)

[13] European Cultural Values.2007. European Commission. Special Eurobarometer 278 / Wave 67. - TNS Opinion \& Social. Available at: http://ec.europa.eu/commfrontoffice/publicopinion/archive s/ebs/ebs_278_en.pdf

[14] Ateca-Amestoy, V. Determining heterogeneous behaviour for theatre attendance. Journal of Cultural Economics, 32. 
pp 127- 151. (2008)

[15] Bernstein, J. S. Arts Marketing Insights: The Dynamics of Building and Retaining Performing Arts Audiences. Jossey-Bass. (2006)

[16] Pop, E.L. \& Borza, A. Factors Influencing Museum Sustainability and Indicators for Museum Sustainability Measurement. MDPI, Open Access Journal, vol. 8(1), pp 1-22. (2016)

[17] Brida, J. G., Meleddu, M. \& Pulina, M. Factors influencing the intention to revisit a cultural attraction: The case study of the Museum of Modern and Contemporary Art in Rovereto. Journal of Cultural Heritage, 13(2), pp. 167-174. (2012)

[18] Bizzozero, P., Flepp, R. \& Franck E. The importance of suspense and surprise in entertainment demand: Evidence from Wimbledon. Journal of Economic Behavior \& Organization. Vol. 130, pp. 47-63. (2016)

[19] Dessy, O. \& Gambaro, M. Demand for Movies in Europe and the Effects of Multiplex Diffusion: A Panel Approach. Universitadegli Studi di Milano Working Paper No. 03. (2009)

[20] Macmillan, P.\& Smith, I. Explaining Post-War Cinema Attendance in Great Britain, Journal of Cultural Economics. Vol. 25, pp 91-108. (2001)

[21] Sisto, A. \& Zanola, R. Rationally Addicted to cinema and TV? An Empirical Investigation if Italian Consumers, Università del Piemonte Orientale, POLIS Working Paper N.52. (2005)

[22] 2011. gada tautas skaitīšanas rezultāti īsumā. Iedzīvotāju augstākais iegūtais izglīīibas līmenis. (2011) Available at: http://www.csb.gov.lv/sites/default/files/publikacijas/nr_13 2011 gada tautas skaitisanas rezultati isuma 12 00 lv.p $\overline{\mathrm{d}} \mathrm{f}$ (In Latvian)

[23] Frequency of museum and concert visits in the UK 2017, by highest education level. The Statistics Portal. Available at: https://www.statista.com/statistics/682270/frequency-of-m useums-and-concert-visits-in-the-united-kingdom-uk-by-e ducation-level/

[24] Falk, M. \& Katz-Gerro, T. Cultural participation in Europe: Can we identify common determinants? Journal of Cultural Economics. Volume 40, Issue 2, pp. 127-162. (2016)

[25] Shavitt, S., Jiang, D. \& Cho, H. Stratification and segmentation: Social class in consumer behavior. Journal of Consumer Psychology, 26 (4), pp. 583-593. (2016)

[26] Veber, M. Klass, status i partiya. Sotsialnaya stratifikatsiya. Pod red. C. Belanovskogo.Vyp. 1. Moskva. (1992) (In Russian)

[27] Kotler, N. G., Kotler, P., \& Kotler, W. I. Museum Marketing and Strategy: Designing Missions, Building Audiences, Generating Revenue and Resources. 2nd Edition. John Wiley \& Sons. (2008)

[28] Lakis, P. Latvijas sabiedrības sociālā stratifikācija 1990. gadusākumā. Latvijas Zinātñu akadēmijas Vēstis, № 4, 8 13.lpp. (1994) (In Latvian)

[29] Latvia. Human Development Report 1999. Riga: UNDP Latvia. Available at: https://digitallibrary.un.org/record/415072

[30] Menshikov, V. Experience of research of social classes in Latvia. Filosofija. Sociologija.V. 27. Nr. 2, pp. 83-92. (2016)

[31] CAF World Giving Index 2015. A global view of giving trends. Charities Aid Foundation Report. 2015. Available at: https://www.cafonline.org/docs/default-source/about-us-pu blications/caf_worldgivingindex2015_report.pdf?sfvrsn $=2$

[32] Ziedot.lv./ Par Ziedot.lv. Available at: https://www.ziedot.lv/par-ziedot-lv (In Latvian)

[33] Teātra apmeklējuma noteicošie faktori un mērķauditorijas identificēšana. Available at: http://www.km.gov.lv/lv/nozares_info/teatris.html (In Latvian) 